\title{
PENGARUH BELLY DANCE DIKOMBINASIKAN DENGANPIJAT ENDORPHIN TERHADAP PENGURANGAN RASA NYERI PADA IBU BERSALIN KALA 1
}

\author{
Hendri P. L Tobing ${ }^{1}$, Renny Sinaga ${ }^{2}$, Kandace Sianipar ${ }^{3}$ \\ Poltekkes Kemenkes Medan ${ }^{123}$ \\ e-mail:*1tobingsitakka@gmail.com, ${ }^{2}$ rennysinaga.75@gmail.com,3kandace.sianipar06@gmail.com
}

\begin{abstract}
Physiologically, all women who give birth will experience pain during labor process and statistically, labor pain cannot be tolerated by two out of three mothers. Women who get massages during labor will experience a significant decrease in anxiety, reduction in pain, and shorter delivery time. No wonder that endorphin massage technique is important to be mastered by pregnant women and husbands who enter the gestational age of the 36th week. The second thing that can be done to deal with the labor pain besides the endorphin massage is dancing. Dancing is a performance art but also can heal and free someone, especially the pregnant women who sufferfrom psychological disorders. The purpose of this study was to determine the effect of belly dance combined with endorphin massage in reducing pain in the first stage of labor at the Beringin Health Center Tapian Dolok District, Simalungun Regency. The hypothesis in this study was belly dance and endorphin massage were effective in reducing pain in primiparous mothers. The type of this research was a quasi-experiment. The design of this study was pre and post-test design. The required number of samples was $16+1.6=17.6$ or $n=18$ samples, that was the sample size for the control group was 18 samples and the sample size for the treatment group was 18 samples, so the total number of samples needed in this study were $n=36$ respondents. The results showed that there was an effect of endorphin massage combined with belly dance (asymp.sig 0.004) on reducing pain in first stage of labor. This study is expected to provide an education to pregnant women about the importance of the belly dance combined with endorphin massage in reducing pain in first stage of labor, so that pregnant women can do a belly dance combined with endorphin massage at home.
\end{abstract}

Keywords: Maternity pain; endorphin massage; belly dance.

\begin{abstract}
ABSTRAK
Secara fisiologis seluruh wanita yang melahirkan akan mengalami nyeri selama proses persalinan dan secara statistik ra sa nyeri persa linan tidak dapat ditoleransi oleh dua daritiga ibu bersalin. Wanita yang mendapat pijatan selama persalinan mengalami penurunan kecemasan, pengurangan nyeri, dan waktu persalinan lebih pendek secara bermakna. Tidak heran jika dikemudian Teknik pijat endorphin ini penting untuk dikuasai ibu hamil dan suami yang mema suki usia kehamilan minggu ke-36. Halkedua selain pijat endorphin untuk mengatasinyeri saat persalinan adalah menari. Tari merupakan seni pertunjukkan akan tetapi menari juga dapat menyembuhkan dan membebaskan seseorang khususnya pada ibu hamil yang menderita gangguan psikologis. Penelitian bertujuan untuk mengetahui pengaruh belly dance dikombinasikan dengan pijat endorphin terhadap pengurangan ra sa nyeri kala 1 persalinan di Puskesmas Beringin Kecamatan Tapian Dolok Kabupaten Simalungun. Hipotes is pada penelitian ini adalah belly dance dan pijat endorphin efektif mengurangi ra sa nyeri pada ibu bersalin primipara. Jenis penelitian yang digunakan adalah quasi eksperimen. Rancangan penelitian ini adalah pre dan post-test design. Dengan jumlah sampel yang diperlukan adalah $16+1,6=17,6$ atau $n=18$ sampel yaitu besar sampel untuk kelompok kontrol sebesar 18 sampel dan besar sampel untuk kelompok treatment sebesar 18 sampel, sehingga jumlah total sampel yang diperlukan dalam penelitian ini adalah $n=36$ responden. Hasil penelitian menunjukkan ada pengaruh belly dance kombinasi endorphin (asymp.sig 0.004) terha dap mengurangi rasa nyeri pada ibu bersalin kala I. Penelitian ini diharapkan dapat memberikan pemahaman kepada ibu hamil mengenai pentingnya belly dance kombinasi pijat endorphin untuk mengurangi ra sa nyeri pada ibu bersa lin kala I, sehingga ibu hamil dapat melakukan belly dance kombinasi pijat endorphin dirumah.
\end{abstract}

Kata kunci: nyeri bersalin; pijat endorphin; bellydance. 


\section{PENDAHULUAN}

\section{Latar Belakang}

Secara fisiologis seluruh wanita yang melahirkan akan mengalami nyeri selama proses persalinan dan secara statistik rasa nyeri persalinan tidak dapat ditoleransi oleh dua dari tiga ibu bersalin..$^{(1)}$ Sebuah penelitian terhadap wanita yang bekerja di Inggris menunjukkan bahwa 93,5\% dari perempuan mendeskripsikan sakit parah atau tak tertahankan,$^{(2)}$ sedangkan di Finlandia $80 \%$ menggambarkannya sebagai nyeri sangat parah atau tak tertahankan. Sebuah studi di Australia melaporkan tingkatan nyeri yang berbeda berdasarkan dilatasi serviks dan menemukan bahwa saat dilatasi serviks $0 \pm 3 \mathrm{~cm}$ itu menyedihkan, $4 \pm 7 \mathrm{~cm}$ adalah mengerikan dan $>8 \mathrm{~cm}$ yang menyiksa. ${ }^{(2)}$

Salah satu terapi farmakologi yang digunakan untuk mengatasi masalah kecemasan karena nyeri persalinan adalah dengan benzodiazepin. Sedangkan beberapa terapi nonfarmakologi yang dapat mengatasi kecemasan ibu hamil adalah dengan pemijatan dan terapi energi seperti massage, acupressure, therapeutic touch, dan healing touch, mind body healing seperti: imagery, meditasi atau yoga, berdoa dan refleksi biofeedback.

Gerakan tarian belly dance telah dimodifikasi untuk ibu hamil. Saat ini masih sangat relatif sedikit penelitian yang berfokus pada efek terapi/gerakan pada penderitagangguan psikologis. Namun, beberapa penelitian menunjukkan hasil ke arah yang positif. Studi penelitian menujukkan bahwa tari perut juga merupakan bentuk olahraga yang sangat baik untuk membantu ibu hamil menguatkan otot-otot yang digunakan selama persalinan. ${ }^{(3)}$

Semakin banyak penelitian yang menunjukkan bahwa olahraga yang teratur mempunyai manfaat bagi ibu dan bayi. Seperti halnya yoga dan tai chi, belly dance merupakan bentuk dari latihan yang menyelaraskan pikiran dan tubuh yang merupakan elemen penting bagi wanita hamil dalam menghadapi kehamilannya. ${ }^{(4)}$

\section{Tujuan Penelitian}

1. Mengetahui tingkat nyeri ibu sebelum diberi perlakuan dan sesudah diberi intervensi belly dance.

2. Mengetahui tingkat nyeri ibu sebelum diberi perlakuan dan sesudah diberi intervensi Kombinasi belly dance dan pijat endhorphin.

3. Menganalisis Pengaruh belly dance dan pijat endorphin terhadap nyeri ibu bersalin primipara di Puskesmas Beringin Kecamatan Tapian Dolok Kabupaten Simalungun.

\section{Hipotesis}

Hipotesis pada penelitian ini adalah belly dance dan pijat endorphin efektif mengurangi rasa nyeri pada ibu bersalin primipara.

\section{METODE}

Jenis penelitian yang digunakan adalah quasi eksperimen. Rancangan penelitian ini adalah pre dan post-test design. Penelitian dilakukan di Puskesmas Beringin Kecamatan Tapian Dolok Kabupaten Simalungun.

Proporsi kasus diambil dari penelitian yang sejenis yaitu penelitian yang dilakukan Porru, et.al. ${ }^{(5)}$ dengan jumlah $\mathrm{P} 1=28$ dan $\mathrm{P} 2=30$. Sehingga dengan menggunakan rumus diatas maka besar sampel yang diperlukan untuk masing-masing kelompok kontrol dan treatment adalah $\mathrm{n}=16,12 / \mathrm{n}=16$.

Berdasarkan antisipasi peneliti adanya drop out dalam proses penelitian ini, menambah jumlah sampel sebesar $10 \%$. Oleh karena itu jumlah sampel yang diperlukan adalah $16+1,6=17,6$ atau $\mathrm{n}=18$ sampel yaitu besar sampel untuk kelompok kontrol sebesar 18 sampel dan besar sampel untuk kelompok treatment sebesar 18 sampel, sehingga jumlah total sampel yang diperlukan dalam penelitian ini adalah $\mathrm{n}=36$ responden.

\section{HASIL}

Tabel 1. Distribusi karakteristik subyek penelitian 
Karakteristik subyek penelitian Tabel 1. didefinisikan sebagai kekhasan subyek atau ciri ciri yang melekat pada subyek penelitian/responden yang membedakan subyek satu dengan lainnya serta memberikan gambaran mengenai sifat - sifat subyek sebagai sasaran dari penelitian. Karakteristik subyek dalam penelitian dilihat berdasarkan tingkat pendidikan formal, pekerjaan, pendidikan dan jumlah anak.

Berdasarkan hasil pengolahan data diketahui bahwa sebagian besar subyek berumur 22-31 tahun yaitu sebanyak $66,6 \%$, mempunyai pendidikan formal setingkat Sekolah Menengah Atas/Kejuruan (SMA/SMK) sebesar 86,11\% diikuti 8,3\% berpendidikan Sekolah Menengah Pertama (SMP) dan 11,1\% berpendidikan Diploma III/S1. Sedangkan untuk pekerjaan sebagian besar subyek menjadi ibu rumah tangga atau tidak bekerja 58,3\% dan $41,6 \%$ bekerja. Sebagian besar subyek mempunyai jumlah anak 1 orang yaitu sebesar $72,2 \%$, anak dua $27,8 \%$. Berdasarkan lama persalinan responden rata-rata memiliki waktu persalinan kurang dari dan sama dengan 5 jam 72,2\%. Karakteristik subyek Tabel 1. secara lengkap sekaligus merupakan hasil analisis univariat.

Tabel 2. Tingkat nyeri responden sebelum intervensi

\begin{tabular}{|c|c|c|c|c|c|c|c|}
\hline \multirow{2}{*}{$\begin{array}{c}\mathrm{N} \\
\mathrm{o}\end{array}$} & Skala & \multicolumn{2}{|c|}{ Belly } & \multicolumn{2}{|c|}{ Kombinas } & \multicolumn{2}{|c|}{ Total } \\
\cline { 3 - 8 } & $\mathrm{i}$ & Dance & \multicolumn{2}{|c|}{$\mathrm{i}$} & \multicolumn{2}{|c|}{} \\
\cline { 3 - 8 } & $\mathrm{n}$ & $\%$ & $\mathrm{n}$ & $\%$ & $\mathrm{n}$ & $\%$ \\
\hline 1 & Seda & 5 & 27, & 4 & 22. & 9 & 25. \\
& $\mathrm{ng}$ & & 8 & & 2 & & 0 \\
\hline 2 & Berat & 1 & 72. & 14 & 77. & 2 & 75. \\
& & 3 & 2 & & 8 & 7 & 0 \\
\hline & Total & 1 & 100 & 18 & 100 & 6 & 100 \\
& & 8 & & & & 0 & \\
\hline
\end{tabular}

Pada Tabel 2. terlihat tingkat nyeri responden sebelum intervensi rata - rata pada kategori berat, yaitu $75 \%$.

Tabel 3. Tingkat nyeri responden setelah intervensi

\begin{tabular}{|c|c|c|c|c|c|c|c|}
\hline \multirow{2}{*}{$\begin{array}{c}\text { N } \\
\text { o }\end{array}$} & \multirow{2}{*}{ Skala } & \multicolumn{2}{|c|}{$\begin{array}{c}\text { Belly } \\
\text { Nyeri }\end{array}$} & \multicolumn{2}{c|}{ Kombin } & \multicolumn{2}{|c|}{ Total } \\
\cline { 3 - 7 } & & $\mathrm{n}$ & $\%$ & $\mathrm{n}$ & $\%$ & $\mathrm{n}$ & $\%$ \\
\hline 1 & Ringa & 0 & 0 & 1 & 5.6 & 1 & 2.7 \\
& $\mathrm{n}$ & & & & & & 7 \\
\hline
\end{tabular}

\begin{tabular}{|c|c|c|c|c|c|c|c|}
\hline \multirow[t]{2}{*}{ No } & \multirow{2}{*}{\multicolumn{2}{|c|}{$\begin{array}{c}\text { Karakteristi } \\
\text { k }\end{array}$}} & \multicolumn{3}{|c|}{$\begin{array}{c}\text { Belly } \\
\text { Dance }\end{array}$} & \multicolumn{2}{|c|}{ Kombinasi } \\
\hline & & & $\mathrm{n}$ & & & $\mathrm{n}$ & $\%$ \\
\hline \multirow[t]{2}{*}{1} & \multicolumn{2}{|c|}{\begin{tabular}{|l} 
Umur \\
$17-21$ \\
tahun \\
$22-31$ \\
tahun \\
$32-36$ \\
tahun
\end{tabular}} & $\begin{array}{l}5 \\
1 \\
1 \\
2\end{array}$ & \multicolumn{2}{|c|}{$\begin{array}{c}27,866 \\
1.1111 \\
, 1\end{array}$} & $\begin{array}{c}3 \\
13 \\
2\end{array}$ & $\begin{array}{l}16,7 \\
72,2 \\
11.1\end{array}$ \\
\hline & \multicolumn{2}{|l|}{ Total } & $\begin{array}{l}1 \\
8\end{array}$ & \multicolumn{2}{|c|}{100} & 18 & 100 \\
\hline \multirow[t]{2}{*}{2} & \multicolumn{2}{|c|}{\begin{tabular}{|l|} 
Pendidikan \\
SMP \\
SMA/SMK \\
Diploma \\
III/S1 \\
\end{tabular}} & $\begin{array}{l}1 \\
1 \\
7 \\
0\end{array}$ & \multicolumn{2}{|c|}{$\begin{array}{l}5,60 \\
94,4\end{array}$} & $\begin{array}{c}2 \\
14 \\
2\end{array}$ & $\begin{array}{l}11.1 \\
77.8 \\
11.1\end{array}$ \\
\hline & \multicolumn{2}{|l|}{ Total } & $\begin{array}{l}1 \\
8 \\
\end{array}$ & \multicolumn{2}{|c|}{100} & 18 & 100 \\
\hline \multirow[t]{2}{*}{3} & \multicolumn{2}{|c|}{$\begin{array}{l}\text { Pekerjaan } \\
\text { Ibu rumah } \\
\text { tangga } \\
\text { Bekerja } \\
\end{array}$} & $\begin{array}{l}1 \\
5 \\
3\end{array}$ & \multicolumn{2}{|c|}{$\begin{array}{l}83,30 \\
16,70\end{array}$} & $\begin{array}{c}6 \\
12\end{array}$ & $\begin{array}{l}33,3 \\
66,7\end{array}$ \\
\hline & \multicolumn{2}{|c|}{ Total } & $\begin{array}{l}1 \\
8\end{array}$ & \multicolumn{2}{|c|}{100} & 18 & 100 \\
\hline \multirow[t]{2}{*}{4} & \multicolumn{2}{|c|}{\begin{tabular}{|l} 
Jumlah \\
kehamilan \\
1 \\
2 \\
3
\end{tabular}} & $\begin{array}{l}1 \\
3 \\
1 \\
5 \\
0\end{array}$ & \multicolumn{2}{|c|}{$\begin{array}{c}72,2 \\
27,8 \\
0\end{array}$} & $\begin{array}{c}13 \\
5 \\
0\end{array}$ & $\begin{array}{c}72.2 \\
27.8 \\
0\end{array}$ \\
\hline & \multicolumn{2}{|l|}{ Total } & $\begin{array}{l}1 \\
8 \\
\end{array}$ & \multicolumn{2}{|c|}{100} & 18 & 100 \\
\hline 5 & \multicolumn{2}{|c|}{$\begin{array}{l}\text { Lama } \\
\text { persalinan } \\
\leq 5 \text { Jam } \\
\geq 6 \text { Jam }\end{array}$} & $\begin{array}{l}1 \\
0 \\
8 \\
\end{array}$ & \multicolumn{2}{|c|}{$\begin{array}{l}55.5 \\
44.4\end{array}$} & $\begin{array}{c}16 \\
2\end{array}$ & $\begin{array}{l}88.8 \\
11.2\end{array}$ \\
\hline 2 & $\begin{array}{c}\text { Sedan } \\
\mathrm{g}\end{array}$ & 2 & 11,1 & $\begin{array}{l}1 \\
2 \\
\end{array}$ & $\begin{array}{c}66, \\
7\end{array}$ & 14 & $\begin{array}{c}38 . \\
8\end{array}$ \\
\hline \multirow[t]{2}{*}{3} & Berat & $\begin{array}{l}1 \\
6 \\
\end{array}$ & 88,9 & 5 & $\begin{array}{c}27 \\
8 \\
\end{array}$ & 21 & $\begin{array}{c}58 . \\
3 \\
\end{array}$ \\
\hline & Total & $\begin{array}{l}1 \\
8\end{array}$ & 100 & $\begin{array}{l}1 \\
8\end{array}$ & 100 & 36 & 100 \\
\hline
\end{tabular}

Pada Tabel 3. pengurangan tingkat nyeri responden setelah intervensi dominan terlihat pada responden dengan perlakuan kombinasi belly dance dan pijat endhorphin, yaitu nyeri sebelum tindakan pada kategori sedang dan berat. Setelah dilakukan intervensi nyeri pada kategori berat dan sedang jumlahnya berkurang dan sebagian responden berubah menjadi nyeri dengan kategori ringan. Sedangkan pada responden dengan perlakuan belly dance saja 


\section{Vol. 15 No. 1 Januari - Apri 2020}

menunjukkan tidak ada perubahan yang signifikan skala nyeri responden.

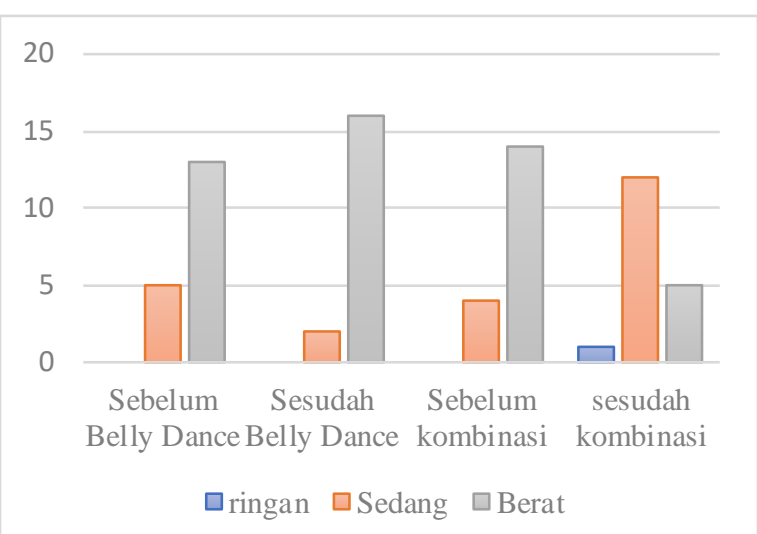

Gambar 1. Distribusi nyeri sebelum dan sesudah tindakan

Pada Gambar 1. Merupakan hasil dari distribusi sebelum dan sesudah belly dance dan kombinasi belly dance dengan pijat endorphin pada ibu bersalin kala 1 fase aktif di Puskesmas Beringin Kecamatan Tapian Dolok Kabupaten Simalungun.

\section{Pengujian Hipotesis menggunakan Wilcoxon Signed Rank Test}

Tes Wilcoxon Signed Rank adalah sebuah tes hipotesis non-parametrik statistik yang digunakan ketika membandingkan dua sampel yang berhubungan atau pengukuran ulang pada sampel tunggal untuk menilai apakah populasi mereka berarti berbeda (yakni merupakan uji perbedaan pasangan). Hal ini dapat digunakan sebagai alternatif untuk uji t student pasangan itu,ketika penduduk tidak dapat diasumsikan terdistribusi secara normal atau data pada skala ordinal.

Tabel 4. Uji Wilcoxon Signed Rank Test perubahan skala responden sebelum dan sesudah intervensi

\begin{tabular}{|c|l|c|c|c|}
\hline $\begin{array}{c}\mathrm{N} \\
\mathrm{o}\end{array}$ & Nyeri & Sebelum & Sesudah & $\mathrm{n}$ \\
\hline 1 & $\begin{array}{l}\text { Belly } \\
\text { Dance }\end{array}$ & & & $0^{\mathrm{a}}$ \\
\hline & Ringan & & & $3^{\mathrm{b}}$ \\
\hline & Sedang & 5 & 2 & \\
\hline & Berat & 13 & 16 & \\
\hline
\end{tabular}

\begin{tabular}{|c|l|c|c|c|}
\hline 2 & $\begin{array}{l}\text { Kombi } \\
\text { nasi }\end{array}$ & & & $11^{\mathrm{a}}$ \\
\hline & Ringan & & 1 & $1^{\mathrm{b}}$ \\
\hline & Sedang & 4 & 12 & \\
\hline & Berat & 14 & 5 & \\
\hline
\end{tabular}

\begin{tabular}{|c|c|c|c|c|}
\hline $\begin{array}{l}\mathrm{N} \\
\mathrm{O}\end{array}$ & Nyeri & $\begin{array}{l}\text { Mean } \\
\text { Rank }\end{array}$ & $\begin{array}{c}\text { Sum Of } \\
\text { Ranks }\end{array}$ & Sig \\
\hline \multirow[t]{4}{*}{1} & $\begin{array}{l}\text { Belly } \\
\text { Dance }\end{array}$ & 0 & \multirow{4}{*}{0} & \\
\hline & Ringan & 2 & & \\
\hline & Sedang & & & $\begin{array}{c}0.08 \\
3\end{array}$ \\
\hline & Berat & & & \\
\hline \multirow[t]{4}{*}{2} & $\begin{array}{l}\text { Kombi } \\
\text { nasi }\end{array}$ & 6.50 & & \\
\hline & Ringan & 6.50 & & \\
\hline & Sedang & & & $\begin{array}{c}0.00 \\
4\end{array}$ \\
\hline & Berat & & & \\
\hline
\end{tabular}

Berdasarkan Tabel 4. diketahui responden yang mengalami nyeri sedang sebelum perlakuan belly dance sebanyak 5 orang $(27,8 \%)$, nyeriberat sebanyak 13 orang $(72,2 \%)$, dan setelah perlakuan belly dance, yang mengalami nyeri sedang sebanyak 5 orang $(27,8 \%)$, nyeri berat sebanyak 13 orang $(72,2 \%)$.

Uji Wilcoxon Signed Rank Test menunjukkan pengaruh belly dance terhadap nyeri ibu bersalin kala I. Hal ini dilihat dari nilai yang diperoleh negative ranks, hasil sebelum dan sesudah belly dance adalah 0 ini menunjukkan tidak ada penurunan (pengurangan) dari nilai sebelum dan sesudah belly dance. Hasil positif ranks menunjukkan hanya 3 responden mengalami peningkatan dengan rata-rata peningkatan sebesar 2,00 , nilai rangking positif sebesar 6,00, nilai ties menunjukkan ada 15 nilai yang sama sebelum dan sesudah perlakuan dan berdasarkan uji statistik yang dilakukan diperoleh nilai asymp.sig 0.083 dapat disimpulkan tidak ada pengaruh belly dance terhadap mengurangi rasa nyeri pada ibu bersalin kala I.

Dari hasil perlakuan sebelum belly dance kombinasi pijat endorphin, nyeri sedang sebanyak 4 orang $(22,2 \%)$, nyeri berat sebanyak 14 orang $(77,8 \%)$, dan setelah dilakukan perlakuan belly dance kombinasi pijat endorphin, nyeri ringan sebanyak 1 orang $(5,6 \%)$, nyeri sedang sebanyak 
12 orang $(66,7 \%)$, nyeri berat sebanyak 5 orang $(27,8 \%), \%)$.

Uji Wilcoxon Signed Rank Test menunjukkan pengaruh belly dance modifasi pijat endorhin terhadap nyeri ibu bersalin kalaI. Hal ini dilihat dari nilai yang diperoleh negative ranks, hasil sebelum dan sesudah belly dance modifasi pijat endorphin adalah 11, ini menunjukkan ada penurunan (pengurangan) dari nilai sebelum dan sesudah belly dance. Hasil Positif Ranks menunjukkan nilai $(\mathrm{N}) 1$ yang menunjukkan rata peningkatan sebesar 6,50 , nilai rangking positif sebesar 6,50 , nilai ties menunjukkan ada 6 nilai yang sama sebelum dan sesudah perlakuan dan berdasarkan uji statistik yang dilakukan diperolehnilai asymp.sig 0.004 dapat disimpulkan ada pengaruh belly dance kombinasi endorphin terhadap mengurangi rasa nyeri pada ibu bersalin kala I.

\section{Post Hoc Tests (Kruskal Wallis)}

Post Hoc Tests merupakan uji lanjutan untuk melihat perbedaan antar kelompok perlakuan, sehingga dapat diketahui perlakuan mana yang paling berpengaruh terhadap perbedaan tingkat kecemasan sesudah dilakukan terapi. Post Hoc Test untuk Kruskal Wallis salah satunya adalah uji Mann Whitney.

Tabel 5. menunjukkan hasil uji Mann Whitney perbedaan rata-rata perubahan tingkat kecemasan pada kelompok belly dance 17,66 lebih rendah dari pada kombinasi belly dance dengan pijat endorphin yaitu 19,44. Dari uji tersebut diperoleh nilai signifikan $0,529(>0,05)$ sehingga dapat disimpulkan bahwa tidak terdapat perbedaan perlakuan yang bermakna pada perlakuan belly dance dan dan tindakan kombinasi belly dance dengan pijat endorphin.

Tabel 5. Uji Post Hoc dengan Mann Whitney perubahan skala nyeri responden belly dance dengan kombinasi belly dance dan pijat endorphin responden mengalami peningkatan dengan rata -

\begin{tabular}{|c|l|c|c|c|}
\hline No & $\begin{array}{c}\text { Jenis } \\
\text { Intervensi }\end{array}$ & Z & $\begin{array}{c}\text { Asymp. } \\
\text { Sig. }(2 \\
\text { Tailed })\end{array}$ & $\begin{array}{c}\text { Asymp. } \\
\text { Sig } \\
(1 \\
\text { Tailed })\end{array}$ \\
\hline 1 & $\begin{array}{l}\text { Belly } \\
\text { Dance }\end{array}$ & 0,629 & 0,529 & $0,606^{\mathrm{b}}$ \\
\hline 2 & Kombinasi & & & \\
\hline
\end{tabular}

Berdasarkan seluruh tahapan dalam analisa data penelitian maka dapat diasumsikan bahwa perlakuan yang paling berpengaruh terhadap perubahan tingkat skala nyeri pada ibu bersalin adalah intervensi yang mengkombinasikan antara belly dance dengan pijat endhorphin. Secara statistik dapat dilihat berdasarkan hasil uji Post Hoc menggunakan Mann Whitneybahwa rata-rata skala nyeri pada kelompok perlakuan ini mempunyai nilai rata-rata yang lebih tinggi dibandingkan dengan kelompok perlakuan yang lain.

\section{PEMBAHASAN}

\section{Karakteristik Responden}

Dalam penelitian ini responden berada dalam kategori usia 17-26 tahun, wanita dengan usia reproduksi tidak sehat memiliki tingkat kecemasan yang lebih tinggi dikarenakan usia <20 tahun organ reproduksinya masih dalam tahap perkembangan sedangkan usia $>35$ tahun masuk dalam kategori kehamilan berisiko terhadap kelainan bawaan dan penyulit pada persalinan.(6) Umur merupakan salah satu faktor predisposisi kecemasan, semakin bertambah usia semakin baik tingkat kematangan emosi seseorang serta kemampuan dalam menghadapi persoalan. Walaupun usia termasuk faktor risiko yang tidak dapat dimodifikasi, kita dapat mengendalikan faktor risiko tersebut dengan merencanakan umur yang ideal bagi wanita untuk hamil yaitu 20-35 tahun yang juga merupakan rentang umur reproduksi sehat.

Pendidikan responden pada penelitian ini adalah dengan tingkat pendidikan SMA $(86,2 \%)$. Tingkat pendidikan dapat mempengaruhi tingkat

\begin{tabular}{|c|c|c|c|c|c|c|}
\hline No & $\begin{array}{c}\text { Jenis } \\
\text { Intervensi }\end{array}$ & $\mathrm{N}$ & $\begin{array}{l}\text { Mean } \\
\text { Rank }\end{array}$ & $\begin{array}{c}\text { Sum } \\
\text { Of } \\
\text { Rank }\end{array}$ & $\begin{array}{c}\text { Mann } \\
\text { Whitney }\end{array}$ & $\begin{array}{l}\text { Tingkat pendidikan dapat mempengaruhi tingkat } \\
\text { Wilcoxpengetahuan responden, oleh karena kemampuan } \\
W \text { sesqorang dalam menerima dan memahami }\end{array}$ \\
\hline 1 & $\begin{array}{l}\text { Belly } \\
\text { Dance }\end{array}$ & 18 & 17,66 & 316,00 & \multirow[t]{2}{*}{145,000} & \multirow{2}{*}{$\begin{array}{l}\text { 316,0 didentukan oleh tingkat pendidikan yang dimiliki. } \\
\text { Penelitian oleh } \mathrm{Ye}^{(7)} \text { menyatakan ibu yang } \\
\text { memiliki pemahaman yang baik tentang proses }\end{array}$} \\
\hline 2 & Kombinasi & 18 & 19,44 & 350,00 & & \\
\hline
\end{tabular}


Rata-rata jumlah persalinan responden pada penelitian ini adalah pada kategori primigravida dan secundigravida. Teori Judha ${ }^{(8)}$ ibu bisa tidak terlalu merasakan sakitnya karena pengalaman yang lalu lebih menyakitkan. Pengalaman pertama yang menyakitkan tersebut akan terekam pada ingatan ibu sehingga ibu dapat mentolelir pada nyeri yang dirasakan setelahnya. Teori Mc Cance ${ }^{(9)}$ juga mendukung hasil penelitian ini yaitu setiap wanita memiliki cara tersendiri dalam merespon atau mengelola stres yang dialami individu. Ibu yang telah memiliki pengalaman akan lebih mampu untuk mengelola nyeri yang ibu rasakan.

Pada penelitian ini didapat hasil rata-rata lama persalinan responden adalah kurang lebih dari 5 jam yaitu $72,2 \%$. Lama kala I untuk primigravida berlangsung 12 jam sedangkan multigravida 8 jam. ${ }^{(10)}$ Menurut JNPK-KR Depkes RI, Kala satu persalian terdiri dari dua fase yaitu fase laten danfase aktif. Lama kala I fase aktif dari pembukaan $4 \mathrm{~cm}$ hingga mencapai pembukaan lengkap $10 \mathrm{~cm}$, akan terjadi dengan kecepatan rata-rata $1 \mathrm{~cm}$ per jam (nulipara atau primigravida) atau lebih dari 1 sampai $2 \mathrm{~cm}$ (multipara). ${ }^{(11)}$

\section{Tingkat Nyeri Ibu Sebelum Diberi Perlakuan dan Sesudah Diberi Intervensi Belly Dance}

Belly dance atau tari perut merupakan salah satu tarian yang berasal dari Timur Tengah. Berkembang dari waktu ke waktu, menyebar ke banyak negara dan sudah menyatu dengan gaya tarian lainnya. Belly dance sangat ideal dilakukan oleh seorang perempuan karena dapat memberikan ketenangan, kelenturan dan kekuatan selama kehamilannya. Selain itu juga ibu hamil dapat menggunakan energinya secara seimbang dan memiliki ef ek yang positif dalam menghadapi permasalahan atau keluhan yang muncul saat hamil, dapat membuat pikiran menjadi rileks dan mengatasi rasa sakit. Aman, efektif dan mendukung wanita selama kehamilan dan persalinan. Gerakan tarian belly dance telah dimodifikasi untuk ibu hamil. Saat ini masih sangat relatif sedikit penelitian yang berfokus pada ef ekterapi/gerakan pada penderita gangguan psikologis. Namun, beberapa penelitian menunjukkan hasil ke arah yang positif. Studi penelitian menujukkan bahwa tari perut juga merupakan bentuk olahraga yang sangat baik untuk membantu ibu hamil menguatkan otot-otot yang digunakan selama persalinan..$^{(3)}$

Hasil penelitian menunjukkan belly dance tidak berpengaruh secara signifikan terhadap penurunan rasa nyeri pada persalinan. Penelitian ini berbeda dengan penelitian oleh Ranita, et.al..$^{(12)}$ yang menyimpulkan belly dance berpengaruh terhadap perbaikan tingkat kecemasan ibu primigravida trimester III, demikian juga halnya dengan penelitian oleh Mariani dan Nunik (13) yang menyimpulkan Ada hubungan yang bermakna antara pelaksanaan senam hamil dengan proses persalinan $(\mathrm{p}=0,00)$. Dengan demikian dapat dijelaskan bahwa ibu yang melakukan senam hamil dengan baik cenderung akan melaksanakan proses persalinannya dengan cepat $(<18$ jam), sebaliknya ibu yang tidak melakukan senam hamil cenderung akan mengalami proses persalinan yang lambat $>24$ jam). Kondisi diatas dapat disebabkan oleh faktor pendukung lainnya yang mempengaruhi respon nyeri faktor umur, merupakan variabel penting yang mempengaruhi nyeri, khususnya pada anakanak dan lansia. Perbedaan perkembangan, yang ditemukan diantara kelompok usia ini dapat mempengaruhi bagaimana anak-anak dan lansia bereaksi terhadap nyeri. Anak belum bisa mengungkapkan nyeri, sehingga perawat harus mengkaji respon nyeri pada anak. Pada orang dewasa kadang melaporkan nyeri jika sudah patologis dan mengalami kerusakan fungsi. Pada lansia cenderung memendam nyeri yang dialami, karena mereka menganggap nyeri adalah hal alamiah yang harus dijalani dan mereka takut kalau mengalami penyakit berat atau meninggal jika nyeri. ${ }^{(14)}$ Faktor Jenis kelamin menurut Gill ${ }^{(15)}$ mengungkapkan laki -laki dan wanita tidak berbeda secara signifikan dalam merespon nyeri, justru lebih dipengaruhi faktor budaya (contoh: tidak pantas kalau laki - laki mengeluh nyeri, sedangkan wanita boleh mengeluh nyeri dalam situasi yang sama). ${ }^{(14)}$

\section{Pengaruh Belly Dance Kombinasi Pijat Endorfin}

Pada umumnya nyeri adalah perasaan yang tidak nyaman yang sangat subyektif dan hanya orang yang mengalaminya yang dapat menjelaskan dan mengevaluasi perasaan tersebut. Hasil penelitian menunjukkan ada pengaruh belly dance kombinasi endorphin terhadap mengurangi rasa nyeri pada ibu bersalin kala I (nilai asymp.sig 
0.004). Penelitian ini sejalan dengan penelitian oleh Ranita, et.al. ${ }^{(12)}$ yang mengatakan Hasil uji hipotesis menunjukkan ada perbedaan bermakna rerata kecemasan pada kelompok intervensi dan kelompok kontrol $(p=, 001)$.

Disimpulkan belly dance berpengaruh terhadap perbaikan tingkat kecemasan ibu primigravida trimester III, dan penelitian yang dilakukan oleh Ekajayanti ${ }^{(16)}$ mengatakan ada pengaruh signifikan Pemberian endorphin massage mempengaruhi kesiapan psikologi ibu hamil TM III dalam menghadapi persalinan di BPM NWB yang ditandai berdasarkan uji statistik dengan nilai $p$ value $0,000<\alpha=0,05$, sehingga Ho ditolak dan Ha diterima. Apabila seorang ibu yang bersalin mampu melakukan relaksasi selama kontraksi maka ibu tersebut akan merasakan kenyamanan selama proses persalinannya.

Penggunaan teknik relaksasi yang benar akan meningkatkan kemampuan ibu dalam mengontrol rasa nyerinya, menurunkan rasa cemas, menurunkan kadar katekolamin, menstimulasi aliran darah menuju uterus, dan menurunkan ketegangan otot. Dalam penelitian ini, kombinasi belly dance dengan pijat endhorphin terbukti memiliki dampak positif dalam menyeimbangkan kondisi psikologis ibu bersalin. Gerakan dalam tarian dipadukan dengan pijatan ini umumnya menenangkan dan dilakukan berulang-ulang sehingga membutuhkan konsentrasi yang dapat mengurangi cemas dan membantu mengurangi rasa nyeri karena kontraksi uterus. Di samping itu gerakan di dalam belly dance dikombinasikan dengan pijat endorphin juga dapat membantu dalam penguatan otot lengan, dada, perut dan panggul, selain itu juga memberikan efek relaksasi pada otot perut dan panggul sehingga persalinan akan jauh lebih lancar. Beberapa responden penelitian ternyata mampu merasakan efek psikologis terhadap keluhan yang dirasakan seperti rasa pegal di punggung.

\section{KETERBATASAN PENELITIAN}

1. Penelitian ini hanya mengambil sampel pada waktu dan jumlah yang terbatas, sehingga untuk penelitian selanjutnya sebaiknya meneliti dengan jumlah sampel yang lebih banyak.

2. Penelitian ini menggunakan teknik purposive sampling dalam pengambilan sampel karena peneliti memerlukan kerjasama dalam pengisian instrumen sehingga hanya memilih ibu yang benar-benar mau bekerjasama. Untuk penelitian selanjutnya sebaiknya digunakan teknik pengambilan sampel yang lebih baik.

3. Pada penelitian ini pengukuran hanya dilakukan pada fase aktif persalinan tanpa ada observasi sejak masa kehamilan .

4. Perbedaan waktu pengukuran nyeri tidak diketahui dengan jelas antara pembukaan 4 $\mathrm{cm}, 5 \mathrm{~cm}, 6 \mathrm{~cm}$ atau $7 \mathrm{~cm}$.

\section{KESIMPULAN}

1. Berdasarkan uji statistik yang dilakukan diperoleh nilai asymp.sig 0.083 dapat disimpulkan tidak ada pengaruh belly dance terhadap mengurangi rasa nyeri pada ibu bersalin kala I.

2. Berdasarkan uji statistik yang dilakukan diperoleh nilai asymp.sig 0.004 dapat disimpulkan ada pengaruh belly dance kombinasi pijat endorphin terhadap mengurangi rasa nyeri pada ibu bersalin kala I.

\section{DAFTAR PUSTAKA}

1. Kastubi, P.Theresia Retno, Purwanto, H, Sutiyana. Pengaruh Relaksasi Dzikir terhadap Nyeri Persalinan Kala I pada Fase Laten Di BPS Kecamatan Pasongsongan Sumenep. Jurnal Keperawatan. 2011;4(1).

2. Baker, A., Ferguson, S.A., Perceptions of Labour Pain by Mothers and Their Attending Midwives. Journal of Advanced Nursing. 2001;35(2):171-179.

3. Waldrop, S. The Benefits of Belly Dance As a Prenatal Exercise. Discover Belly Dance Journal. 2002.

4. Moore, C. Belly Dance for Pregnancy and Birth. Boston. CNM ; 2005.

5. Porru, D., Campus, G., Caria, A., Madeddu, G., Cucchi, A., Rovereto, B., Scarpa, M.R., Pili, P., dan Usai, E. Impact of Early Pelvic Floor Rehabilitation after Transurethral Resection of the Prostate. Neurology and Urodinamics. 2001;20 (1):53-59.

6. Wanda, D., Penurunan Respon Nyeri Akut pada Bayi Prematur yang Dilakukan Prosedur Invasif Melalui Developmental Care. Jumal Keperawatan Indonesia. 2011;14(3). 


\section{Vol. 15 No. 1 Januari - April 2020}

7. Ye, H., Jiang, Y., dan Ruan, Z. Relationship Between Factors Of labour Pain And Delivery Outcomes. 2009;46(10):753-7.

8. Judha, M., Teori Pengukuran Nyeri dan Nyeri Persalinan. Yogyakarta:Nuha Medika;2012.

9. Yanti. Buku Ajar Asuhan Kebidanan Persalinan. Yogyakarta: Pustaka Rihanna ; 2010.

10. Manuaba, I.A.C., Bagus, I., dan Gde, I.B. Ilmu Kebidanan, Penyakit Kandungan dan KB untuk Pendidikan Bidan. Edisi kedua.Jakarta:EGC;2010.173.

11.Depkes RI. Asuhan Persalinan Normal. Jakarta. Depkes RI ; 2008

12. Ranita Bella Ami, Triana SH, Hendri, 2016, Pengaruh Belly dance terhadap tingkat kecemasan ibu hamil Primigravida trimester III di BPM Ranting 3 Kota Semarang, Jurnal Ilmiah Kebidanan Vol 1.no.3 ; 2016.

13. Mariani dan Puspitasari, N., Praktik Senam Hamil Hubungannya dengan Kelancaran Proses Persalinan. The Indonesian Joumal of Public Health.2003;3(1):10-14.

14. Smeltzer, S.C., dan Bare, B.G.Buku Ajar Keperawatan Medikal Bedah Brunner \& Suddart (Alih bahasa Agung Waluyo) Edisi 8 vol.3.Jakarta:EGC; 2002.

15.Gill, K. Psychologic Aspect of Acute Pain. Anesthesiol Rep. 1990; 2(2):246.

16. Ekajayanti, N. Pemberian Endorphin Massage Mempengaruhi Kesiapan Psikologi Ibu Hamil Tm III Dalam Menghadapi Persalinan Di Bpm Nwb Kintamani. Jurnal Dunia Kesehatan.2016;5(2). 